\title{
Police's Role in Investigation Process of Fraud Criminal Act of Civil Servants Candidate (Case Study of Police Station Binjai)
}

\author{
$\underline{\text { Rizkan Zulyadi }}$ \\ Universitas Medan Area (UMA), Medan, Indonesia \\ Email: rizkan@staff.uma.ac.id
}

\begin{abstract}
:
This study tries to discuss the investigation process of civil servants candidate fraud in the jurisdiction of Police Station Binjai, and how are the efforts made by the police in preventing civil servants candidate fraud. The research uses the type of empirical legal research that is a legal research method that functions to see the law in the real sense and examine how the law works in the community. Because in this study examines people in living relationships in the community, empirical legal research methods can be said as sociological legal research. Research conducted based on the study of literature namely books, laws, journals, opinions of legal experts and academics of a scientific nature relating to the problem in writing this thesis. The results obtained are civil servants candidate fraud in the jurisdiction of Police Station Binjai in accordance with procedures, which are carried out by Pro Justitia and Non Pro Justitia with the understanding that there are up to court trials and some only up to the police because between the victims and the suspect made peace and the victim withdrew his complaint so that the police and investigators stopped their investigation on the basis of a North Sumatera Police Chief Telegram letter. Police. : STR / 315 / V / 2011, May 27, 2011 concerning the handling of alternative Dispute Resolution (ADR) cases and also in accordance with the Restotative Justice Principle.
\end{abstract}

Keywords:

police; investigations; fraud; civil servants candidate

\section{Introduction}

Indonesia as a developing country certainly cannot be separated from the influence of the times. These developments not only have a big influence on the country, but also have an impact on the mobility of people's lives, behavior, and cultural shifts in society. Moreover, after the reformation period, the economic, social and cultural conditions of the nation have worsened, not only experiencing an economic crisis but also a moral crisis which has an impact on criminal acts in the general public. Crimes that are common in society today are always related to wealth, and always justifies any means to get it, including committing fraud. Fraud is an act that is detrimental to others, including actions that can be subject to criminal penalties.

According to E. Utrecht, Article 1 paragraph (1) of the Criminal Code contains the understanding that only acts which are declared strictly by the legislation as a crime or violation, can be subject to (criminal) penalties. If in advance there are no laws and regulations which contain sentences that can be imposed on criminals or violators, then the actions in question are not acts that can be subject to punishment.

Fraud is a form of broken promises. And the general nature of broken promises is that the person is made wrong, and therefore he is willing to give up goods or money. Crime fraud includes "materieel delict" meaning to perfection must occur due to (Tri Andrisman, 2011). 
Employment as a Civil Servant is a safe, comfortable and guaranteed old age job, so it is highly sought after by the wider community. Some people are of the opinion that the future of his old age with his family will be guaranteed if he can become a Civil Servant, so that many Indonesian Citizens are competing to register to take the test to become a Civil Servant.

However, being a civil servant is not an easy thing and requires the process of becoming a Candidate for Civil Servants first, this is explained in Law No. 8 of 1974 concerning Principal Personnel in Article 16 Paragraph 2 and 3 which states: "That every citizen who fulfills the specified conditions has the same right to become a Civil Servant" (2).

Law Number 05 Year 2014 concerning State Civil Apparatus Article 87 paragraph (2) Civil Servants can be honorably dismissed or not dismissed because they are sentenced to imprisonment based on a court decision that has permanent legal force for committing a crime with a minimum of 2 (two) prison sentences) years and crimes committed are not planned (Law Number 05 Year 2014 Regarding Civil Apparatus).

\section{Review of Literatures}

\subsection{Definition of Police}

The first time the term Police was discovered in the century BC in Greece is "Politeia" which means the entire city state government. Because at that time cities were independent countries which were also called policies. From the terms polytheia and polis, the terms Lapolice (French), politeia (Dutch), police (English), polzei (German) and Police (Indonesian) emerged. In the large Indonesian dictionary the police are the government bodies that are in charge of maintaining security and public order. Police are all matters relating to the functions and institutions of the police in accordance with statutory regulations. In Law Number. 2 of 2002 concerning the Indonesian National Police "the police are law enforcement officers whose duty is to maintain security, public order" (Pudi Rahardi, 2011).

As an officer in charge of maintaining the security and order of the community, the National Police must prioritize preventive measures such as patrols. In addition to being closer to the community by communicating with residents, by going around the National Police it is faster to act if there are interruptions at any time in the community. So that the implementation of patrols can foster a sense of trust and sympathy from the public (sense of attention) and can foster a sense of assistance to assist the tasks of the National Police, then the ideal abilities of Indonesian National Police members are needed.

\subsection{Definition of Investigation}

Investigators are certain officers of the Indonesian National Police who are given special authority by the Act to conduct an investigation. Investigation is an act of the investigator to find and gather evidence, to make a description of the criminal act that occurred and to find the suspect. As mentioned in article 1 point (1) and article 6 paragraph (1) of the Criminal Procedure Code, what can be said to be investigators is the official of the Republic of Indonesia National Police, which is specifically given by the Law.

Therefore, investigations can only be carried out by investigators if a crime has taken place and an investigation can be carried out according to those stipulated in the Criminal Procedure Code. Investigators are officials of the Indonesian National Police or certain civil servants who are given special authority by the Law to conduct an investigation (Article 109 point (1) of the Criminal Procedure Code). To be able to determine an event that occurs is a 
crime, according to the ability of investigators to identify an event as a crime based on the knowledge of criminal law.

\subsection{Definition of Fraud}

The crime of fraud or bedrog is regulated in Articles 378-395 of the Criminal Code, Book II Chapter XXV. In Chapter XXV the words "Fraud" or "Bedrog" are used, "because in fact in this chapter a number of acts are directed towards property, in which the offender has used acts that are deceptive or used deception."

Fraudulent criminal acts in the principal form are regulated in Article 378 of the Indonesian Penal Code. Article 378 of the Criminal Code Any person with the intention to benefit oneself or another person against the rights, using a false name or false character or using deception or arrangement of hoaxes, moving others to hand over an object or make an act debt agreement or exclude a receivable, because one has committed fraud, sentenced to a prison sentence of up to four years.

\subsection{Definition of Civil Servants Candidate}

Civil Servants Candidate are employees who have just passed the selection test for the first stage of the Prospective Civil Servants, this is explained in Law Number 5 of 2014 concerning State Civil Apparatus, which explains that, Civil Servants are appointed in the rank and position certain government agencies. Appointment of Civil Servants in certain positions is determined based on an objective comparison between competencies, qualifications, and requirements possessed by employees.

Civil Servants Candidate have not followed the obligation to qualify as Civil Servants with a salary of $100 \%$. They are paid a percentage of $80 \%$ based on the civil servants candidate decree that has been determined based on the applicable law in Indonesia. When they are prospective Civil Servants, their competencies and performance are assessed based on the formation when they are declared to pass the selection to become Prospective Civil Servants. If they do not meet the second stage of evaluation criteria, the status of the candidate can be postponed with certain time conditions. If they do not meet the requirements based on the allotted time, they are declared dead or canceled to become Civil Servants.

\subsection{Principles of Crime}

Knowledge about criminal law (positive) can be recognized by several principles that are very important to know, because with the existing principles it can make a relationship and arrangement so that the applicable criminal law can be used systematically, critically, and harmoniously. In essence, getting to know, connect, and arrange the principles in positive criminal law means to carry out the law systematically, critically, and harmoniously in accordance with the dynamics of the lines stipulated in the politics of criminal law. Principles of criminal law by location:

\section{a. Territorial Principle}

This principle is also regulated in the Indonesian Criminal Code (KUHP), which is in article 2 of the Indonesian Criminal Code which states: "Criminal provisions in Indonesian law are applied to everyone who commits a criminal offense in Indonesia". The extension of the Principle of Territoriality is regulated in article 3 of the Law on Laws that states: "Indonesian criminal law provisions apply to anyone outside Indonesia committing a crime in Indonesian water vehicles or aircraft". The purpose of this article is so that criminal acts that occur on ships or airplanes in free waters or in free airspace, are not included in the territorial territory of a country, so that there are those who prosecute if a criminal act occurs. 


\section{b. Principle of Personality (active Nationalite)}

Namely if Indonesian citizens commit crimes even though they occur outside Indonesia, the perpetrators may be subject to Indonesian criminal law, if the perpetrators of crimes can only be subject to Indonesian criminal law while the criminal acts committed by Indonesian citizens in foreign countries who have abolished the death penalty, then the death penalty does not can be imposed on the perpetrators of this crime, this is regulated in article 6 of the Criminal Code.

\section{c. Principle of Protection (National Passive)}

Rejecting the basic thinking of the principle of protection is that every sovereign state is obliged to protect its legal interests or national interests. The main characteristic is the subject in the form of everyone not limited to citizens, other than that it does not depend on the place, it is an act that is felt to be very detrimental to Indonesia's national interests which must therefore be protected.

\section{d. Universal Principle}

The universal principle is the principle which states that every person who commits an act of speech can be prosecuted by Indonesian criminal law laws outside the territory of the State for the benefit of the law for the whole world. This principle sees that the law of speech is generally applicable, transcending the boundaries of territories and people, protected here is the world's interest. The types of crimes contained in speeches according to this principle are very dangerous not only in terms of Indonesia's interests but also the interests of the world. This crime needs to be universally prevented and eradicated.

\section{e. Principle of Legality}

Legally based on the principle of legaliatas contained in article 1 paragraph (1) of the Criminal Code: "No act can be criminalized, except for the strength of criminal rules in existing legislation, before the action is carried out" In Latin: "Nullum delictum nulla poena sine praevia legi poenali ", which can be interpreted literally in Indonesian by:" There is no offense, there is no criminal without a criminal provision that precedes it ". The Latin term is often used: "Nullum crimen sine lege stricta", which can be interpreted as: "There is no offense without strict provisions".

\section{f. Principle of Transitoir}

It is a principle that determines the enactment of a rule of criminal law in the event of a change or law.

\section{g. Retroactive Principle}

Retroactive principle is a legal principle that can be applied retroactively. This means that the law that aru made can be applied to criminal acts that occurred in the past as long as the law regulates these actions, for example in gross human rights violations. Indonesian criminal law basically adheres to the principle of legality as regulated in Article 1 paragraph (1) of the Criminal Code which states "No act can be convicted except for the strength of criminal rules in legislation that existed before the act was carried out". One consequence of the provisions of the article is the prohibition of applying retroactively a criminal legislation or what is known as the retroactive principle. Initially, the prohibition of retroactive enforcement of a criminal regulation is contained in Article 6 Algemene Bepalingen van Wetgeving voor Nederlands Indie (AB) S.1947-23, then appears in the Constitution, namely UUDS 1950 Article 14 paragraph (2). 


\section{Research Methods}

The research location is the place or area chosen as a place for data collection in the field to find answers to the problems studied. This research is conducted directly to Binjai Resort Police, Sultan Hasanuddin Street, No. 1 Binjai. In this study, the researcher uses empirical legal research, a legal research method that functions to see the law in the real sense and examine how law works in the community. This research uses Library Research and Field Research.

\section{Discussion}

Investigators are certain officers of Indonesian National Police who are given special authority by the Act to conduct an investigation. Investigation is an act of the investigator to find and gather evidence, to make a description of the criminal act that occurred and to find the suspect. As mentioned in Article 1 paragraph (1) and Article 6 paragraph (1) of the Criminal Procedure Code, what can be said as an investigator is an official of the Republic of Indonesia National Police who is given special authority by the Law. A person appointed as an investigator must fulfill the requirements that support this task, such as: having knowledge, expertise in addition to the requirements for rank. However, the Criminal Procedure Code does not specifically address this issue.

The government as a policy to regulate the growth rate of Civil Servants Candidate. The high interest of the community to become civil servants, and the history of CPNS recruitment policies that are inconsistent. In the 1999-2004 period, the CPNS zero growth policy by only recruiting new Civil Servants Candidate for replacing civil servants who retire, are fired, or resign, so far seen as one of the opportunities to become a civil servant. Despite zero growth, the actual growth of civil servants has never really been zero percent.

\subsection{Process of Investigating Criminal Acts of Civil Servants Candidate Fraud in the Legal Area of the Binjai Regional Police}

In Article 1 point (2) of Law No.8 of 1981 concerning the Criminal Procedure Code (KUHAP) it is stated that: "Investigation is a series of investigative actions in terms of and according to the way regulated in this law to search for and gathering evidence that makes clear about the crime that occurred and to find the suspect ". Therefore, investigations can only be carried out by investigators if a crime has taken place and an investigation can be carried out according to those stipulated in the Criminal Procedure Code. Investigators are officials of the Indonesian National Police or certain civil servant officials who are given special authority by the Law to carry out investigations (Article 109 item (1) of the Criminal Procedure Code). To be able to determine an event that occurs is a crime, according to the ability of investigators to identify an event as a crime based on the knowledge of criminal law.

The authority of the Investigator in investigating / examining cases of CPNS Fraud is regulated as follows:

1) Article 5 paragraph (2) of the Criminal Procedure Code reads that the Investigator makes and submits it report on the results of the implementation of the actions referred to in paragraph 1 letter $a$ and letter $b$ to the investigator.

2) Article 7 paragraph (1) of the Criminal Procedure Code reads that the Investigator as referred to in Article 6 letter has the duty and authority to:

Receive reports or complaints from someone about criminal action;

- Take the first action at the scene; 
- Telling someone to stop and check a letter or ID concerned;

- Making arrests, detention, search, confiscation, investigation letters and wiretaps;

- Taking fingerprints and photographing someone;

- Calling people to be examined as suspects or asked for information as a witness;

- Listen to the expert information needed in relation to case investigation;

- Carry out an end to the investigation;

- Conduct a covert observation of a crime; and

- Perform other actions in accordance with regulatory requirements

3) Article 11 of the Criminal Procedure Code reads Assistant investigators have such authority mentioned in Article \& paragraph (1), except regarding detention that must be given with delegation of authority from the investigator

4) Article 16 paragraph (1) of the Criminal Procedure Code reads for the purpose of investigation, investigators by order of investigators authorized to make an arrest

5) Article 18 paragraph (1) of the Criminal Procedure Code reads The implementation of the arrest task is carried out by the Republic of Indonesia police officers by showing an arrest warrant that includes the identity of the suspect and specifies the reason for the arrest and a brief description of the crime case that was arrested and where he was investigated.

6) Article 33 Paragraph (2) of the Criminal Procedure Code reads In case it is required by written order from the investigator, the Indonesian National Police officers can enter the house.

7) Article 38 paragraph (1) of the Criminal Procedure Code reads confiscation can only be carried out by investigators with the permission of the chairman of the local district court.

8) Article 47 paragraph 1 of the Criminal Procedure Code reads that the investigator has the right to open, inspect and confiscate other letters sent through the post office and telecommunications, services or communications or transportation companies if the object is suspected of having strong grounds related to the criminal case being examined, with special permission granted for that from the chair of the state court.

9) And contained in Law No. 2 of 2002 concerning the Republic of Indonesia's National Police.

Civil Servants Candidate Fraud criminal process in Police Station Binjai jurisdiction has proceeded according to the procedure, which was carried out by Pro Justitia and Non Pro Justitia with the understanding that there was a trial at the court and some only reached the police only because between the victim and the suspect made peace and the victim withdraw the complaint so that the Police or Investigator stop the investigation on the basis of the North Sumatra Police Chief Telegram Letter No. Pol.: STR / 315 / V / 2011, May 27, 2011 concerning handling alternative Dispute cases Resolution (ADR) and also in accordance with the Restorative Justice Principle.

The principle of restorative justice (restorative justice) is as an important development in human thought based on the justice traditions of ancient Arabs, Greeks, Romans and civilizations that accepted a restorative approach even to murder cases, the restorative approach of the general assembly (Moots) of Germanic societies that swept across Europe after the fall of Rome, Indian Hinduism is as ancient as the Vedic of Civilization for whom "he who redeems is forgiven", and ancient Buddhism, Taoism, and the Confucian tradition that he sees mixed with Western influences today in North Asia. Restorative Justice or known as "reparative justice" is an approach to justice that focuses on the needs of the victims, perpetrators of crime, and also involves the participation of the community, and does not merely fulfill the legal requirements or merely impose criminal. 
In this case victims are also involved in the process, while perpetrators of crimes are also encouraged to take responsibility for their actions, namely by correcting the mistakes they have made by apologizing, returning stolen money, or by doing community service. In terms of examining Civil Servants Candidate who commit fraud do not use the rules of ASN Law No.5 of 2014 because the Rules in investigating Civil Servants Candidate fraud cases are the same as ordinary fraud cases.

Enforcement carried out by the Binjai Regional Police in Civil Servants Candidate Fraud case is Receiving Complaints at the SPKT from the Reporting Party or the victim and then forwarding it to the Criminal Investigation Unit, then the Criminal Investigation Unit makes a Disposition to the Unit where the Report is in disposition to handle it and then the Investigator or Assistant Investigator appointed to handle it. complete the Investigation Administration to conduct an Investigation of the Report in order to obtain 2 (two) pieces of evidence and after that be upgraded to the Investigation and then conduct an examination of the victim witnesses and other witnesses who are aware of the incident and confiscate evidence in the victim or witnesses and then conduct a Case Title to increase the status of a suspect and conduct an examination of the suspect and subsequently file a file, then after filing, send the Case File to the Binjai District Prosecutor's Office and After the Prosecutor's Office declares the File The case is Complete or (P-21), then the duties and responsibilities of the Police Submit the suspect and Evidence to the Binjai District Attorney but if the Prosecutor's Office states that the Case File is incomplete (P-18), the Case File is returned to the Investigator or Assistant Investigator with instructions from the Prosecutor (P-19) to be completed and after completing the Case File sent back to Binjai District Prosecutor's Office, it was stated as complete (P21) by the State Prosecutor's Office.

\subsection{Efforts made by the police in the prevention of Civil Servants Candidate Fraud}

Reports on Civil Servants Candidate fraud cases from 2011 to 2013 have increased but since 2014 until now reports on Civil Servants Candidate Fraud cases have declined because their acceptance has used the CAT (Computer Assisted Test) system, which means that Registration and test implementation uses Computer or computerized systems (On line) is a method of selection or recruitment system with computer aids to get a minimum standard of basic competency for Civil Servants Candidate applicants. Purpose and Objectives, namely:

a. Speed up the examination process and report on exam results

b. Creating a standardized national exam results

c. Setting value standards

Advantages of Using the CAT System Test participants can register via the internet Test participants can be assessed directly in accordance with the results obtained Computer provides all the material Basic Competency questions (General Knowledge Test, Scholastic Talent Test and Maturity Scale Test) Assessment is carried out objectively Examinees can easily access towards achieving the results (score) obtained.

The efforts of the police in investigating criminal acts are essentially part of law enforcement, therefore it is often also said, that political or judicial policies are also part of law enforcement policies. Rational efforts to tackle these criminal acts of fraud by the police conduct investigations through Preventive and Refressive Efforts. There are two attempts, namely:

\section{a. Preventive Efforts}

Preventive efforts are efforts undertaken to prevent crime from occurring. Which is still on the level of prevention before the crime. In a preventive effort the emphasis is on eliminating the opportunity to do so. For example there are people who want to steal a 
motorcycle but the opportunity is eliminated because the existing motorbikes are placed in the day care of the motorbike, so the opportunity becomes and does not occur crime. So in a preventive effort the opportunity is closed.

\section{b. Refressive Efforts}

Refressive efforts are carried out when a criminal act has taken place in the form of law enforcement by imposing a sentence. Repressive effort is an attempt to deal with a conceptual crime taken after the occurrence of a criminal offense. Countermeasures with repressive efforts to act against the perpetrators in accordance with their actions and improve it again so that they realize that the act that was done is an act that violates the law and is detrimental to the community, so that it does not repeat it and others will also not do it given the sanctions are very heavy.

\section{Conclusion}

The process of Civil Servants Candidate fraud in the jurisdiction of Police Station Binjai has proceeded according to the procedure which was carried out in a pro justitia and non pro justitia with the understanding that there was trial until the trial in court and some only reached the police because between the victim and the suspect made peace and the victim withdrew his complaint so that the police or the investigator stops his investigation on the basis of the North Sumatera Police Chief Telegram letter. Police: STR / 315 / V / 2011, May 27, 2011 concerning handling alternative dispute resolution (ADR) cases and also in accordance with the Restorative Justice Principles.

Fraudulent candidates for civil servants are caused by many factors that make Civil Servants Candidate fraud cases because of the desire to commit fraud and opportunities provided by victims in the form of trust and intention of victims carried out in the wrong way and the factor of the perpetrators' gaps to enter someone into a civil servant through the insertion and economic factors of actors in the form of urgent needs. The obstacles in the investigation of fraud cases of Civil Servants Candidate cases include that the report received was not enough good evidence in the form of a letter that is without a receipt of money and the absence of witnesses who know the victim handed over his money to the perpetrators.

The efforts of the police and investigators in handling Civil Servants Candidate fraud cases are appealing to prospective civil servants (victims) and their parents to make a complaint report as a basis for the police to investigate and investigate Civil Servants Candidate fraud cases.

\section{References}

Andi hamzah. (2017). Asas - asas hukum pidana edisi revisi,Rineka cipta, Jakarta.

Bassar, Sudrajat. (2008). Tindak-Tindak Pidana Tertentu Dalam KUHP, Remaja Karya, Bandung.

E.Utrecht / Moh. Saleh Djindang. (1983). Pengantar Dalam Hukum Indonesia, Ichtiar Baru dan Sinar Harapan, Jakarta.

Moeljatno. (2000). Asas-asas Hukum Pidana, Rineka Cipta, Jakarta

P.A.F Lamintang. (2009). Dasar-Dasar Hukum Pidana Indonesia, Sinar Baru, Bandung.

Pudi Rahardi, (2014). Hukum Kepolisian ,Laksbang Grafika, Surabaya.

R. Soesilo. (1980). Taktik dan Teknik Penyidikan Perkara Kriminil, Politea, Bogor.

Satjipto Rahardjo. (1996).

Ilmu Hukum, PT Citra Aditya Bakti, Bandung. 
Sitompul,DPM, ,Beberapa Tugas dan Wewenang Polisi, Divisi Pembinaan Hukum Polri, Jakarta, 2004

Undang-Undang Nomor 05 Tahun 2005 Tentang Aparatur Sipil Negara (ASN)

Undang-Undang Nomor 1 Tahun 1946 Tentang Kitab Undang-Undang Hukum Pidana (KUHP)

Undang-Undang Nomor 8 Tahun 1981 Tentang Kitab Undang-Undang Hukum Acara Pidana (KUHAP)

Undang-Undang No 8 Tahun 1974 tentang Pokok-pokok Kepegawaian

Undang-undang Nomor 2 Tahun 2002 tentang Kepolisian Republik Indonesia

Peraturan Pemerintah Nomor 11 tahun 2012 tentang perubahan atas Peraturan

Pemerintah Nomor 98 tahun 2000 tentang Pengadaan Pegawai Negeri Sipil 